\title{
Enhancement of antioxidant and storability of Hollywood plum cultivar by preharvest treatments with moringa leaf extract and some nutrients
}

\author{
Thanaa Shaban Mohamed Mahmoud ${ }^{1 *}$ (D, Fatma Korany Mohamed Shaaban² and Gehan Abd El-Malek El-Hadidy ${ }^{2}$
}

\begin{abstract}
Background: Plum fruit has a short shelf life with a rapid deterioration in quality after harvest. The main aim of this study was to evaluate the effect of preharvest treatments by moringa leaf extract (MLE), boric acid (B), and chelated calcium (Ca EDTA) on Hollywood plum fruit quality attributes bioactive compounds and antioxidant activity during cold storage. Plum trees were sprayed twice: at full bloom stage and 1 month later with $\mathrm{T} 1,5 \% \mathrm{MLE}+1 \% \mathrm{~B}+2 \%$ Ca EDTA; T2, 5\% MLE + 2\% B + 3\% Ca EDTA; T3, 10\% MLE + 1\% B + 2\% Ca EDTA; T4, 10\% MLE + 2\% B + 3\% Ca EDTA; and T5, water only as control. At maturity stage, fruits were harvested and stored at $0 \pm 1{ }^{\circ} \mathrm{C}$ and $\mathrm{RH} 85-90 \%$ for 8 weeks.

Results: At the end of storage, all studied treatments exhibited significantly higher sensory quality: firmness, color, soluble solid content:titratable acidity ratio, total anthocyanin content, total flavonoids content, total phenolic content, and antioxidant activity than control.

Conclusions: It could be concluded that preharvest treatment with moringa leaf extract, boric acid, and chelated calcium could be a safe and eco-friendly to improve and maintain plum quality attributes and especially their content of antioxidant compounds during cold storage periods.
\end{abstract}

Keywords: Plum, Moringa leaf extract, Boric acid, Chelated calcium, Cold storage, Phenolic, Antioxidant activity, Quality

\section{Introduction}

Plum (Prunus domestica L. cv. Hollywood) is climacteric fruit with a limited postharvest storage life due to the physicochemical changes associated with ripening, such as changes in color, texture, total soluble solids, and titratable acidity, which accelerated by ethylene production. Moreover, fruit continues to respire even after harvest that leads to increase postharvest losses. These losses can be visualized in terms of shrinkage which renders the softening of the fruits and lose their commercial quality in a short period (Lelièvre et al. 1997). There

\footnotetext{
* Correspondence: thanaa_3000@yahoo.com

'Department of Horticultural Crops Technology, National Research Centre, Dokki, Giza, Egypt

Full list of author information is available at the end of the article
}

were many effective ways to prolong fruit storability. These ways have a direct effect on fruit quality and their postharvest behavior among these ways is the preharvest mineral nutrition treatments. Mineral nutrition is reported to influence the storage fruits' quality in many ways. Of particular importance is calcium, a deficiency of which may induce a range of postharvest disorders in several fruits (Shear 1975).

Calcium has been reported to maintain the cell wall structure in fruits by interacting with pectins in the cell wall to form calcium pectate which assists molecular bonding between constituents of the cell wall (Dong et al. 2000). Calcium also increases cell turgor pressure and stabilizes the cell membrane (Hernandez and Munoz 2006). Calcium is known to strengthen the 
structure of cells by maintaining the fibrillary packaging in the cell walls thus reinforcing the cell to cell contact which is related to the formation of calcium pectate and counteracts the pectin methyl esterase, peroxidases, and catalases activity (Alandes et al. 2009; Shirzadeh and Kazemi 2011). It is also known to bind with the free carboxylic group released during degradation of cell wall component (Degraeve et al. 2003) by pectin methyl esterase and polygalacturanase and thus improves the fruit firmness, slow down ripening process, and prolonging shelf life of fruits.

Boron is an essential micronutrient required for optimal yield and fruit quality. It is important in pollen tube growth, successful fruit set, and formation of feeder roots. Symptoms of boron deficiency include internal and external core formation in fruits and the development of small-deformed fruits (Donald et al. 1998). Boron influenced the metabolic activities by interacting with magnesium, calcium, and vitamin D (Chapin et al. 1998). Boron has disinfectant and bactericidal properties which suppress the postharvest rotting in fruit and plays an important role in maintaining the rigidity of cell wall and phenolic concentration (Pilbeam and Kirkby 1983). Exogenous application of boron was shown to alleviate the occurrence of browning in fruits during controlled atmosphere storage (Xuan et al. 2005). Due to the association of boron with antioxidant enzymes, it prevents oxidative damage of the fungal pathogen (Shi et al. 2012). Foliar applications of boric acid improve the physical and chemical characteristics, enhance the storage life of apple fruits (Khalifa et al. 2009), retarded the degradation of color, titratable acidity, soluble solid content, and maintained higher fruit firmness and total phenolic content of stored "Patharnakh" pear than control (Kaur et al. 2019). Spraying boron in combination with calcium increased the fruit firmness, total soluble solid, and total sugar contents and reduced fruit decay and phenol contents during storage of date palm fruits (Omaima et al. 2011) and Florida Prince peach (Hemat et al. 2014).

Moringa (Moringa oleifera L.) is one of such alternatives, being investigated to ascertain its effect on growth and yield of crops and thus can be promoted among farmers as a possible supplement or substitute to inorganic fertilizers (Phiri and Mbewe 2010). Different parts of this plant contain a profile of important minerals, proteins, vitamins, $\beta$ carotene, amino acids, and various phenolics and provide a rich and rare combination of zeatin with several flavonoid pigments (Siddhuraju and Becker 2003). So it is a good source of natural antioxidants (Jacob and Shenbagaraman 2011). Several studies pointed out that spraying moringa leaf extract increased the yield and percentage of marketable fruit and decreases in number and percentage unmarketable fruits
(Sheren and El-Amary 2015; Nasira et al. 2016). Moreover, it increases ascorbic acid, anthocyanin content, and antioxidant activity of Hollywood plum (Thanaa et al. 2017).

The aim of this research was to evaluate the effect of preharvest treatments by combination of moringa leaf extract, boric acid, and chelated calcium on fruit quality attributes and antioxidant of Hollywood plum fruits during cold storage.

\section{Materials and methods}

This study was carried out during two successive seasons 2018 and 2019 on 10 years old Hollywood plum trees (Prunus domestica L.) budded on Marianna (P. cerasifera $x$ P. munsoniana) plum rootstock and planted at $5 \times 5$ $\mathrm{m}$ in loamy clay soil. Trees were irrigated by surface irrigation system in a private orchard at Ashmoun, Menofia Governorate, Egypt. Fifteen trees uniform in vigor, trained on open vase training system, were chosen randomly as three trees/treatment. Selected trees were sprayed twice: at full bloom stage and 1 month later during the years 2018 and 2019. The treatments applied were as follows:
T1, $5 \%$ MLE + 1\% B + 2\% Ca EDTA
T2, $5 \%$ MLE + $2 \%$ B + 3\% Ca EDTA
T3, $10 \%$ MLE $+1 \%$ B + $2 \%$ Ca EDTA
T4, 10\% MLE + 2\% B + 3\% Ca EDTA
$\mathrm{T} 5$, water only (control)

\section{Preparation of moringa leaf extract}

The aqueous extract of moringa leaves was prepared by soaking $100 \mathrm{~g}$ of air-dried moringa leaves in $1 \mathrm{l}$ of water for $24 \mathrm{~h}$ then filtered and diluted with water to $5 \%$ and $10 \%$. Trees were sprayed directly with this solution thoroughly till it run off. Tween- 20 at $0.01 \%$ was added as a surfactant.

Plum fruits were harvested at maturity stage in the first week of June during each studying seasons. Fruits were free from apparent pathogen infection, uniform in shape, weight, and color picked separately from each treatment. Fruits were transported to the laboratory and packed in perforated carton boxes in three replicates for each treatment. Each treatment packed in six boxes; it is classified into three groups. First group contains fruits for periodical determination of the physical and chemical properties, second group contains fruits for determination of the weight loss, and third group contains fruits for determination of the decay percentage. Fruits stored at $0 \pm 1{ }^{\circ} \mathrm{C}$ with relative humidity (RH) $85-90 \%$ for 8 weeks. Assay of the stored fruits was determined at 2-week intervals, as follows:

\section{Physical properties \\ Weight loss percentage}

The difference between the initial weight of the fruits at the beginning of storage and that recorded at the date of 
sampling was translated as weight loss percentage and calculated as follows:

$$
\text { Weight loss } \%=\frac{\text { Weight at the date of sampling }(\mathrm{g})}{\text { Initial weight of the fruits }(\mathrm{g})} \times 100
$$

\section{Fruit Firmness (Lb/inch ${ }^{2}$ )}

Fruit firmness was determined as $\mathrm{Lb} / \mathrm{inch}^{2}$ by using fruit pressure tester mod. FT 327 (3-27 Lbs).

\section{Fruit color}

Lightness and hue angle were estimated using Minolta Calorimeter (Minolta Co. Ltd., Osaka, Japan) as described by (Mc Gire 1992).

\section{Decay percentage}

The percentage of disordered fruits included all of the spoiled fruits resulted from rots, fungus, bacterial, and pathogens were assessed and the defects were calculated as follows:

$$
\text { Decay } \%=\frac{\text { No.of fruit decay }}{\text { No. of fruit at the beginning of storage }} \times 100
$$

\section{Chemical properties}

\section{Soluble solid content (SSC):titratable acidity (TA) ratio}

Percentage of SSC was determined in plum fruit juice using Digital refractometer PR32 $(0.32 \%$ Atago Palete ATago.CO . LTD. Japan); TA was determined by titrating the juice against $0.1 \mathrm{~N}$ sodium hydroxide using phenolphthalein indicator and expressed as percentage of malic acid according to AOAC (2000) and then the SSC: TA ratio was calculated.

\section{Total anthocyanin content (TAC)}

TAC in juice was evaluated spectrophotometrically using the $\mathrm{pH}$ differential method (Giusti and Wrolstad 2001).

\section{Total flavonoid content (TFC)}

The TFC was measured by a colorimetric assay developed by (Zhishen et al. 1999). The TFC was expressed as mg quercetin equivalents (QE)/100 g extract.

\section{Total phenolic content (TPC)}

TPC in juice was determined using the Folin-Ciocalteu method (Meighani et al. 2014). Total phenolic content was expressed as mg gallic acid equivalent in $100 \mathrm{~mL}$ of juice (mg gallic acid/100 mL juice).

\section{Antioxidant activity (AA)}

AA was assessed according to the method explained by Ismail et al. (2009). The antioxidant activity is expressed in the form of the percentage of free radical scavenging.

\section{Statistical analysis}

A randomized complete block design was used to analysis of variance for comparison between the control and the other. Treatment data were subjected to statistical analysis according to the procedures reported by (Snedecor and Cochran 1990) and means were compared by Duncan's multiple range tests at the $5 \%$ level of probability.

\section{Results \\ Physical properties \\ Weight loss percentage}

Data shown in Table 1 clearly indicated that weight loss percentage increased gradually and significantly with extending cold storage periods with significant differences between them during two seasons in this work. The least value weight loss percentage (5.72 and $6.81 \%$ ) was obtained by $10 \%$ MLE $+1 \%$ B $+2 \%$ Ca EDTA in both seasons, respectively. On the other hand, fruits treated with $5 \%$ MLE $+1 \%$ B $+2 \%$ Ca EDTA exhibited the highest value of weight loss percentage $(7.19$ and $10.40 \%)$ in the two seasons, respectively.

As for interaction, significant differences were detected in the interaction between the two studied factors (preharvest treatments and storage periods). After 8 weeks of storage, the least value of weight loss percentage $(13.24$ and $12.00 \%$ ) was obtained by fruits treated with $10 \%$ MLE $+1 \%$ B $+2 \%$ Ca EDTA in the first and second seasons, respectively. On the other hand, the highest value of weight loss percentage $(15.68 \%$ in the first season and

Table 1 Effect of preharvest spraying with moringa leaf extract, boric acid, and chelated calcium on weight loss percentage of Hollywood plum fruits stored at $0 \pm 1{ }^{\circ} \mathrm{C}$ and $\mathrm{RH} 85-90 \%$ during

\begin{tabular}{|c|c|c|c|c|c|c|}
\hline \multirow[t]{2}{*}{ Treatments } & \multicolumn{6}{|c|}{ Storage period per weeks } \\
\hline & 0 & 2 & 4 & 6 & 8 & Mean \\
\hline & \multicolumn{6}{|c|}{ First season; 2018} \\
\hline T1 & $0.00 \mathrm{u}$ & $1.82 n$ & $4.22 k$ & $14.25 \mathrm{~g}$ & $15.68 \mathrm{a}$ & $7.19 \mathrm{~A}$ \\
\hline T2 & $0.00 \mathrm{u}$ & $1.07 \mathrm{~s}$ & $2.84 \mid$ & $13.31 \mathrm{~h}$ & $14.29 f$ & $6.30 \mathrm{D}$ \\
\hline T3 & $0.00 \mathrm{u}$ & $1.12 r$ & $1.40 \mathrm{q}$ & $12.83 j$ & $13.24 i$ & $5.72 \mathrm{E}$ \\
\hline T4 & $0.00 \mathrm{u}$ & $0.39 t$ & $1.62 p$ & $14.81 d$ & $15.17 \mathrm{c}$ & $6.40 \mathrm{C}$ \\
\hline Control & $0.00 \mathrm{u}$ & 1.690 & $2.22 \mathrm{~m}$ & $14.67 e$ & $15.55 b$ & $6.83 B$ \\
\hline \multirow[t]{2}{*}{ Mean } & $0.00 \mathrm{E}$ & $1.22 \mathrm{D}$ & $2.46 \mathrm{C}$ & 13.97B & $14.79 \mathrm{~A}$ & \\
\hline & \multicolumn{6}{|c|}{ Second season; 2019} \\
\hline $\mathrm{T} 1$ & $0.00 \mathrm{u}$ & $1.53 p$ & $14.94 \mathrm{~g}$ & $17.55 d$ & $18.00 \mathrm{a}$ & $10.40 \mathrm{~A}$ \\
\hline T2 & $0.00 \mathrm{u}$ & $3.92 p$ & $11.73 k$ & $15.03 f$ & $16.34 \mathrm{e}$ & $9.40 \mathrm{~B}$ \\
\hline T3 & $0.00 \mathrm{u}$ & $2.95 q$ & $7.46 n$ & 11.621 & $12.00 \mathrm{j}$ & $6.81 \mathrm{E}$ \\
\hline T4 & $0.00 \mathrm{u}$ & $1.74 \mathrm{~s}$ & $9.52 \mathrm{~m}$ & $12.48 \mathrm{i}$ & $13.05 \mathrm{~h}$ & $7.36 \mathrm{D}$ \\
\hline Control & $0.00 \mathrm{u}$ & $2.26 r$ & 5.990 & $17.86 \mathrm{c}$ & $17.97 \mathrm{~b}$ & $8.82 \mathrm{C}$ \\
\hline Mean & $0.00 \mathrm{E}$ & $2.48 \mathrm{D}$ & $9.93 C$ & 14.91B & $15.47 \mathrm{~A}$ & \\
\hline
\end{tabular}
2018 and 2019 seasons

Means in each column with similar letters are not significantly different 
$18.00 \%$ in the second one) was obtained by fruits treated with $5 \%$ MLE $+1 \%$ B + $2 \%$ Ca EDTA.

\section{Fruit firmness}

Data shown in Table 2 illustrated that fruit firmness declined towards the end of storage period ( 8 weeks). Data also cleared that all treatments significantly reduced the rate of fruit firmness decline during storage compared with control fruits. The highest firmness value was obtained by $10 \%$ MLE $+1 \% \mathrm{~B}+2 \%$ Ca EDTA treatment in the two seasons.

Concerning the interaction effect, it is clear that significant differences were detected in most treatments. After 8 weeks of storage, the highest values of firmness (2.24 and $2.40 \mathrm{Lb} /$ inch $^{2}$ ) were obtained by $10 \% \mathrm{MLE}+$ $1 \% \mathrm{~B}+2 \%$ Ca EDTA and $5 \%$ MLE $+1 \%$ B + $2 \%$ Ca EDTA in the first and second seasons, respectively. However, the least value of firmness $(1.27$ and $2.27 \mathrm{Lb} /$ inch $^{2}$ ) was recorded by control fruits in both seasons, respectively.

\section{Fruit color}

Lightness $\left(\mathbf{L}^{*}\right)$ Data shown in Table 3 indicated that lightness $\left(L^{*}\right)$ decreased gradually significant with prolonging of storage period during the two seasons.

Data also cleared that fruits treated by $10 \%$ MLE $+1 \%$ $\mathrm{B}+2 \%$ Ca EDTA recorded the highest significant difference of $L^{*}$ in the two seasons (31.20 and 33.44), respectively, while fruits treated by $5 \%$ MLE $+1 \% \mathrm{~B}+2 \% \mathrm{Ca}$

Table 2 Effect of preharvest spraying with moringa leaf extract, boric acid, and chelated calcium on firmness $\left(\mathrm{Lb} /\right.$ inch $\left.^{2}\right)$ of Hollywood plum fruits stored at $0 \pm 1{ }^{\circ} \mathrm{C}$ and $\mathrm{RH} 85-90 \%$ during 2018 and 2019 seasons

\begin{tabular}{|c|c|c|c|c|c|c|}
\hline \multirow[t]{2}{*}{ Treatments } & \multicolumn{6}{|c|}{ Storage period per weeks } \\
\hline & 0 & 2 & 4 & 6 & 8 & Mean \\
\hline & \multicolumn{6}{|c|}{ First season; 2018} \\
\hline T1 & $3.27 \mathrm{bc}$ & $3.27 b c$ & 2.80de & $2.40 f-i$ & $2.13 \mathrm{ij}$ & 2.77B \\
\hline $\mathrm{T} 2$ & $3.40 \mathrm{~b}$ & $2.53 \mathrm{e}-\mathrm{g}$ & 2.80de & $2.60 \mathrm{ef}$ & $2.23 \mathrm{~h}-\mathrm{j}$ & $2.71 B$ \\
\hline T3 & $3.27 \mathrm{bc}$ & 2.80de & $2.30 \mathrm{~g}-\mathrm{i}$ & $2.30 \mathrm{~g}-\mathrm{i}$ & $2.24 \mathrm{~h}-\mathrm{j}$ & $2.58 \mathrm{C}$ \\
\hline T4 & $3.87 a$ & $3.67 a$ & $3.00 \mathrm{~cd}$ & $2.50 f-h$ & $2.20 \mathrm{ij}$ & $3.05 \mathrm{~A}$ \\
\hline Control & $3.20 \mathrm{bc}$ & $2.37 f-i$ & 2.00j & $1.40 \mathrm{k}$ & $1.27 \mathrm{k}$ & 2.05D \\
\hline \multirow[t]{2}{*}{ Mean } & $3.40 \mathrm{~A}$ & $2.93 B$ & $2.58 \mathrm{C}$ & $2.24 \mathrm{D}$ & $2.01 \mathrm{E}$ & \\
\hline & \multicolumn{6}{|c|}{ Second season; 2019} \\
\hline $\mathrm{T} 1$ & $4.87 a$ & 3.50de & 3.23ef & $2.40 \mathrm{ij}$ & $2.40 \mathrm{ij}$ & $3.28 \mathrm{C}$ \\
\hline T2 & $4.90 \mathrm{a}$ & 3.43de & $3.03 \mathrm{fg}$ & $2.57 \mathrm{~h}-\mathrm{j}$ & $2.28 \mathrm{j}$ & $3.24 C$ \\
\hline T3 & $4.92 \mathrm{a}$ & $3.57 c-e$ & $3.83 \mathrm{C}$ & $3.70 \mathrm{~cd}$ & $2.28 \mathrm{j}$ & $3.66 \mathrm{~B}$ \\
\hline T4 & $5.09 a$ & $3.63 \mathrm{~cd}$ & 4.80a & $3.27 \mathrm{ef}$ & 2.30j & $3.82 \mathrm{~A}$ \\
\hline Control & $4.27 \mathrm{~b}$ & 3.37de & 2.83gh & 2.67hi & $2.27 \mathrm{j}$ & $3.08 \mathrm{D}$ \\
\hline Mean & $4.81 \mathrm{~A}$ & $3.50 \mathrm{~B}$ & $3.55 \mathrm{~B}$ & $2.92 \mathrm{C}$ & $2.30 \mathrm{D}$ & \\
\hline
\end{tabular}

Means in each column with similar letters are not significantly different
EDTA exhibited the lowest values of $\mathrm{L}^{*}$ (28.15 and 28.08) in the first and second seasons, respectively.

As for interaction between treatments and storage periods, we noted significant effect on $L^{*}$ in both seasons of study. At the end of storage period, 5\% MLE + 1\% B $+2 \%$ Ca EDTA and 10\% MLE + 1\% B + 2\% Ca EDTA treatments gave the highest values of $\mathrm{L}^{*}$ (25.67 and 25.47 ) in the first and second seasons, respectively. Meanwhile, control treatment exhibited the lowest value of L* (20.71 and 21.44) during 2017 and 2018 seasons.

Hue angle $\left(h^{\circ}\right)$ Hue angle $\left(h^{\circ}\right)$ was decreased (increase density of red color) with the advance in cold storage period (Table 4). Significant differences between all treatments were observed in 2018 and 2019 seasons. The lowest value of $h^{\circ}$ (high density of red color) in the two seasons was recorded by $10 \%$ MLE $+1 \% \mathrm{~B}+2 \% \mathrm{Ca}$ EDTA. On the other hand, the highest values were recorded with control fruits in both seasons.

As for interaction, there was a significant effect between the preharvest treatments with moringa leaf extract, boric acid, and chelated calcium and storage periods on $\mathrm{h}^{\circ}$. It is clear from Table 4 that in the end of storage period, $5 \% \mathrm{MLE}+1 \% \mathrm{~B}+2 \%$ Ca EDTA recorded highest values of hue angle in the two seasons. On the contrary, control and 10\% MLE + 1\% B + 2\% Ca EDTA treatments gave the least values of hue angle in the first and second seasons, respectively.

\section{Decay percentage}

It is clear from the data in Fig. 1 that all treatments significantly decreased decay percentage than the control fruits. However, all the used treatments did not give any decay fruits before 8 weeks of storage.

After 8 weeks of storage, data cleared that fruits treated by $5 \%$ MLE $+1 \%$ B $+2 \%$ Ca EDTA recorded the lowest significant difference of decay percentage ( 2 and $5 \%$ in the two seasons, respectively. On the contrary, control fruit treatment exhibited the highest values of decay percentage (26.6\% and $30.3 \%)$ in the first and second seasons, respectively.

\section{Chemical properties \\ Soluble solid content (SSC):titratable acidity (TA) ratio}

Regarding the changes in SSC:TA ratio during cold storage period, the results revealed that there was an increase until the 4th week storage (26.86 and 24.91) and then steadily decreased up to 8 week $(8.88$ and 8.68$)$ in two seasons, respectively (Table 5). SSC:TA ratio was affected significantly as result of preharvest spraying with moringa leaf extract, boric acid, and chelated calcium during both seasons. Control treatment and fruit treated by $10 \%$ MLE $+2 \%$ B + 3\% Ca EDTA gave the highest significant differences in the two seasons, respectively, 
Table 3 Effect of preharvest spraying with moringa leaf extract, boric acid, and chelated calcium on $L^{*}$ of Hollywood plum fruits stored at $0 \pm 1{ }^{\circ} \mathrm{C}$ and $\mathrm{RH} 85-90 \%$ during 2018 and 2019 seasons

\begin{tabular}{|c|c|c|c|c|c|c|}
\hline \multirow[t]{2}{*}{ Treatments } & \multicolumn{6}{|c|}{ Storage period per weeks } \\
\hline & 0 & 2 & 4 & 6 & 8 & Mean \\
\hline & \multicolumn{6}{|c|}{ First season; 2018} \\
\hline T1 & $31.64 \mathrm{e}$ & $28.70 \mathrm{fg}$ & $28.23 f-i$ & $26.49 i-k$ & $25.67 \mathrm{kl}$ & $28.15 C$ \\
\hline T2 & $32.90 \mathrm{e}$ & $32.76 \mathrm{e}$ & $27.81 \mathrm{~g}-\mathrm{j}$ & $26.59 \mathrm{~h}-\mathrm{k}$ & $24.67 \mid$ & 28.95B \\
\hline T3 & $38.54 b c$ & $39.01 b$ & $29.73 f$ & $28.03 f-i$ & $20.89 m$ & $31.20 \mathrm{~A}$ \\
\hline T4 & $41.71 a$ & $35.51 d$ & $28.40 f-h$ & $26.78 \mathrm{~h}-\mathrm{k}$ & $21.97 \mathrm{~m}$ & $30.87 \mathrm{~A}$ \\
\hline Control & $36.40 d$ & $37.21 \mathrm{~cd}$ & 24.641 & $25.97 \mathrm{j}-1$ & $20.71 \mathrm{~m}$ & $29.00 B$ \\
\hline \multirow[t]{2}{*}{ Mean } & $36.24 A$ & $34.64 \mathrm{~B}$ & $27.76 \mathrm{C}$ & 26.77D & $22.78 \mathrm{E}$ & \\
\hline & \multicolumn{6}{|c|}{ Second season; 2019} \\
\hline T1 & 31.43de & $32.47 d$ & $26.74 \mathrm{i}-1$ & 25.82j-m & $23.91 n$ & 28.08D \\
\hline T2 & $36.53 c$ & $37.14 \mathrm{c}$ & $25.29 \mid-n$ & $27.33 \mathrm{~h}-\mathrm{j}$ & 21.720 & $29.60 \mathrm{C}$ \\
\hline T3 & $41.84 a$ & $41.55 \mathrm{a}$ & $28.97 f-h$ & $29.34 \mathrm{fg}$ & $25.47 k-n$ & $33.44 \mathrm{~A}$ \\
\hline T4 & $39.76 b$ & 31.52de & 30.39ef & $28.22 \mathrm{~g}-\mathrm{i}$ & $24.59 \mathrm{mn}$ & $30.90 \mathrm{~B}$ \\
\hline Control & $30.73 d-f$ & $32.28 d$ & $28.98 f-h$ & $27.11 \mathrm{i}-\mathrm{k}$ & 21.440 & 28.11D \\
\hline Mean & $36.06 \mathrm{~A}$ & $34.99 \mathrm{~B}$ & $28.07 C$ & $27.57 \mathrm{C}$ & 23.43D & \\
\hline
\end{tabular}

Means in each column with similar letters are not significantly different

while $5 \%$ MLE $+2 \% \mathrm{~B}+3 \%$ Ca EDTA recorded the least value in both seasons.

The interaction between the two studied factors was significant in the effect on SSC:TA ratio. At the end of storage periods ( 8 weeks), the highest values were recorded by control fruit in the first season and 5\% MLE + $1 \% \mathrm{~B}+2 \% \mathrm{Ca}$ EDTA in the second one. On the

Table 4 Effect of preharvest spraying with moringa leaf extract, boric acid, and chelated calcium on hue angle of Hollywood plum fruits stored at $0 \pm 1{ }^{\circ} \mathrm{C}$ and $\mathrm{RH}$ 85-90\% during 2018 and 2019 seasons

\begin{tabular}{|c|c|c|c|c|c|c|}
\hline \multirow[t]{2}{*}{ Treatments } & \multicolumn{6}{|c|}{ Storage period per weeks } \\
\hline & 0 & 2 & 4 & 6 & 8 & Mean \\
\hline & \multicolumn{6}{|c|}{ First season; 2018} \\
\hline $\mathrm{T} 1$ & $27.89 \mathrm{e}$ & $27.24 \mathrm{e}$ & $23.41 f$ & $22.17 \mathrm{fg}$ & 19.72hi & $24.09 C$ \\
\hline T2 & $43.69 a$ & $42.80 \mathrm{a}$ & 20.09hi & $18.21 \mathrm{ij}$ & $17.34 \mathrm{jk}$ & $28.42 A$ \\
\hline T3 & $31.08 d$ & $28.14 \mathrm{e}$ & $19.00 \mathrm{~h}-\mathrm{j}$ & $17.54 \mathrm{jk}$ & $17.34 \mathrm{jk}$ & $22.62 \mathrm{D}$ \\
\hline T4 & $33.39 c$ & $36.18 b$ & $20.92 \mathrm{gh}$ & $18.60 i j$ & $16.03 \mathrm{kl}$ & 25.02B \\
\hline Control & $44.38 a$ & $28.14 \mathrm{e}$ & $19.47 \mathrm{~h}-\mathrm{j}$ & $19.40 \mathrm{~h}-\mathrm{j}$ & 14.791 & $28.49 \mathrm{~A}$ \\
\hline \multirow[t]{2}{*}{ Mean } & $36.08 \mathrm{~A}$ & $35.75 \mathrm{~A}$ & $20.58 B$ & $19.18 \mathrm{C}$ & 17.05D & \\
\hline & \multicolumn{6}{|c|}{ Second season; 2019} \\
\hline $\mathrm{T1}$ & $24.86 \mathrm{~g}$ & $25.47 \mathrm{fg}$ & $21.34 \mathrm{~h}$ & 19.72hi & $17.54 \mathrm{j}-\mathrm{n}$ & $21.78 \mathrm{E}$ \\
\hline T2 & $40.74 b$ & $41.89 \mathrm{~b}$ & $17.26 k-n$ & $17.021-n$ & $16.10 \mathrm{mn}$ & $26.60 B$ \\
\hline T3 & $28.83 \mathrm{e}$ & $27.20 \mathrm{ef}$ & $24.08 \mathrm{~g}$ & $19.13 i-k$ & $15.57 n$ & 22.96D \\
\hline T4 & $37.42 c$ & $32.10 \mathrm{~d}$ & $18.15 i-\mid$ & 19.75hi & $16.50 \mid-n$ & $24.78 \mathrm{C}$ \\
\hline Control & $47.17 a$ & $47.74 a$ & $17.87 \mathrm{i}-\mathrm{m}$ & $19.37 \mathrm{ij}$ & $17.52 \mathrm{j}-\mathrm{n}$ & 29.94A \\
\hline Mean & $35.80 A$ & $34.88 \mathrm{~B}$ & $19.74 C$ & $19.00 \mathrm{C}$ & 16.65D & \\
\hline
\end{tabular}

Means in each column with similar letters are not significantly different contrary, 5\% MLE $+2 \% \mathrm{~B}+3 \%$ Ca EDTA exhibited the least value in both seasons.

\section{Total anthocyanin content (TAC)}

It is clear from the tabulated data in Table 6 that all treatments significantly increased total anthocyanin content than the control fruits. However, total anthocyanin content increased with the advance in cold storage period. The highest value (19.73 and 19.95\%) was recorded by $10 \%$ MLE $+1 \%$ B $+2 \%$ Ca EDTA in both seasons, respectively. On the other hand, control treatment exhibited least values (16.65 and 17.10\%) in the first and second seasons, respectively.

Regarding the interaction between the two studied factors, there were significant differences in the effect on total anthocyanin content. After 8 weeks of storage, the highest values (20.35 and 20.51\%) were recorded by fruits treated with 10\% MLE + 2\% B + 3\% Ca EDTA and $5 \%$ MLE $+2 \%$ B $+3 \%$ Ca EDTA in the first and second seasons, respectively. However, the least values (19.00 and $20.13 \%$ ) were found by control treatment in the two seasons, respectively.

\section{Total flavonoid content (TFC)}

Data shown in Table 7 indicated that total flavonoid content decreased gradually significant with extended of the storage periods during the two seasons in this work. Moreover, total flavonoid content significantly increased by preharvest spraying with moringa leaf extract, boric acid, and chelated calcium (Tables 7). In both seasons, the highest value was obtained by fruits treated with 


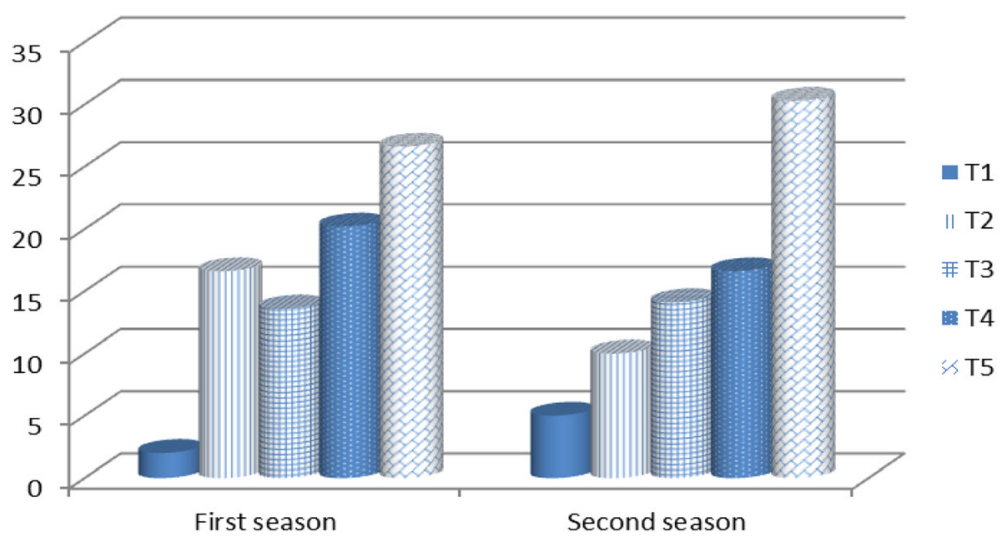

Fig. 1 Effect of preharvest spraying with moringa leaf extract, boric acid, and chelated calcium on decay percentage after 8 weeks of Hollywood plum fruits stored at $0 \pm 1{ }^{\circ} \mathrm{C}$ and $\mathrm{RH} 85-90 \%$ during 2018 and 2019 seasons

$10 \%$ MLE + 1\% B + 2\% Ca EDTA, while the least value of total flavonoid content was recorded by control treatment.

Due to the interaction between the two studied factors, the highest values of total flavonoid content after 8 weeks of storage (16.12 and 16.25) were obtained by fruits treated with $10 \% \mathrm{MLE}+2 \% \mathrm{~B}+3 \% \mathrm{Ca}$ EDTA and $10 \%$ MLE $+1 \%$ B $+2 \%$ Ca EDTA in the first and second seasons, respectively, while the least value of total flavonoid content was found with $5 \%$ MLE $+1 \%$ B $+2 \%$ Ca EDTA in the two seasons.

Table 5 Effect of preharvest spraying with moringa leaf extract, boric acid, and chelated calcium on SSC:TA ratio in fruit juice of Hollywood plum stored at $0 \pm 1{ }^{\circ} \mathrm{C}$ and RH 85-90\% during 2018 and 2019 seasons

\begin{tabular}{|c|c|c|c|c|c|c|}
\hline \multirow[t]{2}{*}{ Treatments } & \multicolumn{6}{|c|}{ Storage period per weeks } \\
\hline & $\overline{0}$ & 2 & 4 & 6 & 8 & Mean \\
\hline & \multicolumn{6}{|c|}{ First season; 2018} \\
\hline T1 & $9.71 \mathrm{ij}$ & $9.95 i$ & $26.73 b c$ & 8.80jk & 8.80jk & $12.80 \mathrm{C}$ \\
\hline T2 & $7.98 k$ & $7.96 k$ & $27.61 \mathrm{a}$ & $9.00 j$ & $8.77 \mathrm{jk}$ & $12.26 \mathrm{D}$ \\
\hline T3 & $13.49 f$ & $12.92 \mathrm{~g}$ & $26.76 b c$ & 10.27hi & $9.03 j$ & $14.49 \mathrm{~B}$ \\
\hline T4 & $8.81 \mathrm{jk}$ & $24.33 d$ & $26.11 \mathrm{~cd}$ & $9.94 \mathrm{i}$ & $8.77 \mathrm{jk}$ & $12.68 \mathrm{C}$ \\
\hline Control & $11.00 \mathrm{~h}$ & $21.68 \mathrm{e}$ & $27.07 a b$ & 10.23hi & $9.03 j$ & $15.80 \mathrm{~A}$ \\
\hline \multirow[t]{2}{*}{ Mean } & $9.94 \mathrm{C}$ & 15.37B & $26.86 \mathrm{~A}$ & $9.65 C$ & 8.88D & \\
\hline & \multicolumn{6}{|c|}{ Second season; 2019} \\
\hline T1 & $9.04 j \mathrm{k}$ & $11.66 \mathrm{~g}$ & $22.28 \mathrm{e}$ & $8.97 k$ & $9.00 \mathrm{k}$ & $12.19 \mathrm{D}$ \\
\hline T2 & 7.511 & $8.48 k$ & $26.37 a$ & $8.80 \mathrm{k}$ & $8.50 \mathrm{k}$ & $11.93 \mathrm{D}$ \\
\hline T3 & $10.26 \mathrm{~h}$ & $9.86 \mathrm{ij}$ & $25.35 b$ & 10.27hi & $8.58 k$ & $12.86 \mathrm{C}$ \\
\hline T4 & 10.67hi & $22.89 d$ & $26.39 a$ & $9.90 h-j$ & $8.53 \mathrm{k}$ & $15.67 \mathrm{~A}$ \\
\hline Control & $10.13 \mathrm{~h}$ & $13.45 f$ & $24.16 c$ & $9.94 h-j$ & $8.80 \mathrm{k}$ & $13.30 \mathrm{~B}$ \\
\hline Mean & $9.52 \mathrm{C}$ & $13.27 \mathrm{~B}$ & $24.91 \mathrm{~A}$ & $9.58 \mathrm{C}$ & $8.68 \mathrm{D}$ & \\
\hline
\end{tabular}

Means in each column with similar letters are not significantly different
Total phenolic content (TPC)

As shown in Table 8, total phenolic content increased significantly by the conducted treatments and the storage periods. The highest value of total phenolic content (91.55 and 93.77) was recorded by $10 \%$ MLE $+1 \% \mathrm{~B}+$ $2 \% \mathrm{Ca}$ EDTA in both seasons, respectively. On the other hand, control treatment exhibited least values (81.62 and 82.77 ) in the first and second seasons, respectively.

The effect of interaction between preharvest treatments with moringa leaf extract, boric acid, and chelated calcium and storage periods on total phenolic content was significant (Table 8) in both seasons. After 8 weeks

Table 6 Effect of preharvest spraying with moringa leaf extract, boric acid, and chelated calcium on total anthocyanin content of Hollywood plum fruits stored at $0 \pm 1{ }^{\circ} \mathrm{C}$ and $\mathrm{RH} 85-90 \%$ during 2018 and 2019 seasons

\begin{tabular}{|c|c|c|c|c|c|c|}
\hline \multirow[t]{2}{*}{ Treatments } & \multicolumn{6}{|c|}{ Storage period per weeks } \\
\hline & 0 & 2 & 4 & 6 & 8 & Mean \\
\hline & \multicolumn{6}{|c|}{ First season; 2018} \\
\hline T1 & $15.23 w$ & $16.22 \mathrm{u}$ & $17.17 q$ & $16.34 i$ & $20.08 c$ & 17.61D \\
\hline $\mathrm{T} 2$ & $16.33 \mathrm{~s}$ & 17.320 & $18.17 \mathrm{~m}$ & 19.91e & $20.18 b$ & $18.38 \mathrm{C}$ \\
\hline T3 & $19.19 j$ & $19.55 \mathrm{~h}$ & $19.73 f$ & $20.01 d$ & $20.18 b$ & $19.73 \mathrm{~A}$ \\
\hline T4 & $16.81 \mathrm{r}$ & $17.23 p$ & 18.911 & $19.60 \mathrm{~g}$ & $20.35 a$ & $18.58 \mathrm{~B}$ \\
\hline Control & $14.62 x$ & $15.34 \mathrm{v}$ & $16.28 t$ & $18.00 n$ & $19.00 \mathrm{k}$ & $16.65 \mathrm{E}$ \\
\hline \multirow[t]{2}{*}{ Mean } & $16.44 \mathrm{E}$ & 17.13D & $18.05 \mathrm{C}$ & 19.37B & $19.96 \mathrm{~A}$ & \\
\hline & \multicolumn{6}{|c|}{ Second season; 2019} \\
\hline T1 & $15.05 r$ & $16.19 p$ & $17.39 n$ & $19.00 \mathrm{k}$ & $20.15 b c$ & $17.56 \mathrm{D}$ \\
\hline T2 & $18.04 \mathrm{~m}$ & $19.11 j$ & $19.38 \mathrm{~h}$ & $20.00 k$ & $20.51 a$ & $19.41 C$ \\
\hline T3 & $19.82 \mathrm{~g}$ & $19.89 f$ & $19.90 f$ & $20.00 \mathrm{k}$ & $20.18 c$ & $19.95 \mathrm{~A}$ \\
\hline T4 & 19.10j & $19.25 i$ & $19.89 f$ & $20.00 k$ & $20.18 b$ & 19.70B \\
\hline Control & $14.11 \mathrm{~s}$ & $15.37 q$ & 17.090 & $18.76 \mid$ & $20.13 b$ & $17.10 \mathrm{E}$ \\
\hline Mean & $17.22 \mathrm{E}$ & 17.96D & $18.73 \mathrm{C}$ & 19.56B & $20.23 \mathrm{~A}$ & \\
\hline
\end{tabular}

Means in each column with similar letters are not significantly different 
Table 7 Effect of preharvest spraying with moringa leaf extract, boric acid, and chelated calcium on total flavonoid content of Hollywood plum fruits stored at $0 \pm 1{ }^{\circ} \mathrm{C}$ and $\mathrm{RH} 85-90 \%$ during 2018 and 2019 seasons

\begin{tabular}{|c|c|c|c|c|c|c|}
\hline \multirow[t]{2}{*}{ Treatments } & \multicolumn{6}{|c|}{ Storage period per weeks } \\
\hline & 0 & 2 & 4 & 6 & 8 & Mean \\
\hline & \multicolumn{6}{|c|}{ First season; 2018} \\
\hline T1 & $18.36 \mathrm{e}$ & $18.07 \mathrm{~g}$ & $17.07 \mid$ & $15.08 q$ & $14.90 \mathrm{~s}$ & 16.70D \\
\hline T2 & $20.09 a$ & $19.01 c$ & $18.11 \mathrm{~g}$ & $16.11 n$ & $15.27 p$ & $17.72 \mathrm{~B}$ \\
\hline T3 & $19.82 b$ & $19.01 \mathrm{C}$ & $18.02 \mathrm{~h}$ & $17.33 j$ & 16.020 & $18.04 \mathrm{~A}$ \\
\hline T4 & $18.16 f$ & $18.10 \mathrm{~g}$ & $17.11 \mathrm{k}$ & $16.12 n$ & $16.12 n$ & $17.12 \mathrm{C}$ \\
\hline Control & $18.58 \mathrm{~d}$ & $17.79 i$ & $16.55 \mathrm{~m}$ & $15.11 q$ & $15.00 r$ & $16.61 \mathrm{E}$ \\
\hline \multirow[t]{2}{*}{ Mean } & $19.00 \mathrm{~A}$ & $18.40 \mathrm{~B}$ & $17.37 \mathrm{C}$ & 15.95D & $15.46 \mathrm{E}$ & \\
\hline & \multicolumn{6}{|c|}{ Second season; 2019} \\
\hline T1 & $20.32 c$ & $19.01 \mathrm{~h}$ & 18.211 & $17.25 p$ & $16.00 \mathrm{v}$ & $18.16 \mathrm{C}$ \\
\hline T2 & $20.25 d$ & $19.00 \mathrm{hi}$ & $18.05 \mathrm{~m}$ & 17.330 & $16.22 s t$ & $18.17 \mathrm{C}$ \\
\hline T3 & $20.89 a$ & $19.36 f$ & $18.34 j$ & $17.41 n$ & $16.25 \mathrm{~s}$ & $18.45 \mathrm{~A}$ \\
\hline $\mathrm{T} 4$ & $20.17 e$ & $19.00 \mathrm{hi}$ & $18.97 i$ & $17.00 \mathrm{q}$ & $16.13 u$ & 18.25B \\
\hline Control & $20.57 b$ & $19.21 \mathrm{~g}$ & $18.25 \mathrm{k}$ & $16.37 r$ & $16.20 t$ & $18.12 \mathrm{D}$ \\
\hline Mean & $20.44 A$ & 19.12B & $18.36 \mathrm{C}$ & 17.07D & 16.16E & \\
\hline
\end{tabular}

Means in each column with similar letters are not significantly different

of storage, the highest values of total phenolic content (91.88 and 93.97) were recorded by fruits treated with $10 \%$ MLE $+1 \%$ B $+2 \%$ Ca EDTA in the first and the second seasons, respectively. On the side, the least values of total phenolic content (81.89 and 83.43) were found with control treatment in the two seasons, respectively.

Table 8 Effect of preharvest spraying with moringa leaf extract, boric acid, and chelated calcium on total phenolic content of Hollywood plum fruits stored at $0 \pm 1{ }^{\circ} \mathrm{C}$ and $\mathrm{RH} 85-90 \%$ during 2018 and 2019 seasons

\begin{tabular}{|c|c|c|c|c|c|c|}
\hline \multirow[t]{2}{*}{ Treatments } & \multicolumn{6}{|c|}{ Storage period per weeks } \\
\hline & 0 & 2 & 4 & 6 & 8 & Mean \\
\hline & \multicolumn{6}{|c|}{ First season; 2018} \\
\hline $\mathrm{T} 1$ & $86.89 p$ & $86.90 p$ & $86.93 p$ & 86.990 & 87.030 & 86.95D \\
\hline $\mathrm{T} 2$ & $87.77 n$ & $87.90 \mathrm{~m}$ & 87.951 & $89.00 f$ & $89.02 f$ & $88.33 C$ \\
\hline T3 & $91.20 \mathrm{e}$ & $91.33 d$ & $91.56 \mathrm{c}$ & $91.77 b$ & $91.88 a$ & $91.55 \mathrm{~A}$ \\
\hline T4 & $88.04 k$ & $88.32 j$ & $88.54 i$ & $88.60 \mathrm{~h}$ & $88.84 \mathrm{~g}$ & 88.47B \\
\hline Control & $81.34 \mathrm{u}$ & $81.47 t$ & $81.65 \mathrm{~s}$ & $81.73 r$ & $81.89 q$ & $81.62 \mathrm{E}$ \\
\hline \multirow[t]{2}{*}{ Mean } & 87.05E & 87.18D & $87.33 C$ & $87.62 B$ & $87.73 \mathrm{~A}$ & \\
\hline & \multicolumn{6}{|c|}{ Second season; 2019} \\
\hline T1 & $86.90 \mathrm{~s}$ & $86.95 r$ & $87.00 q$ & $87.05 p$ & 87.440 & 87.07D \\
\hline T2 & $90.10 n$ & $90.55 \mathrm{~m}$ & 90.711 & $90.83 k$ & $90.91 j$ & $90.62 \mathrm{C}$ \\
\hline T3 & $93.50 \mathrm{e}$ & $93.67 d$ & $93.81 \mathrm{c}$ & $93.89 b$ & $93.97 a$ & 93.77A \\
\hline T4 & $92.91 \mathrm{i}$ & $92.98 \mathrm{~h}$ & $93.00 \mathrm{~h}$ & $93.07 \mathrm{~g}$ & $93.19 f$ & $93.03 \mathrm{~B}$ \\
\hline Control & $82.45 x$ & $82.53 w$ & $82.67 v$ & $82.79 u$ & $83.43 t$ & 82.77E \\
\hline Mean & 89.17E & 89.34D & $89.44 C$ & $89.53 B$ & $89.79 A$ & \\
\hline
\end{tabular}

Means in each column with similar letters are not significantly different

\section{Antioxidant activity (AA)}

Results presented in Table 9 show that all studied treatments increased antioxidant activity than the control fruits. However, antioxidant activity decreased with the advance in cold storage period.

The highest value of antioxidant activity (67.89 and 66.00 ) was recorded by $10 \%$ MLE $+1 \%$ B $+2 \% \mathrm{Ca}$ EDTA in both seasons, respectively. On the other hand, control treatment gave the least values of antioxidant activity (59.07 and 63.04) in the first and second seasons, respectively.

Concerning the interaction effect, results in Table 9 indicated that antioxidant activity was significantly affected by preharvest treatments with moringa leaf extract, boric acid, and chelated calcium and storage periods. After 8 weeks of storage, the highest values of antioxidant activity (62.14) were recorded by fruits treated with $10 \%$ MLE $+1 \% \mathrm{~B}+2 \%$ Ca EDTA in the first season and (63.00) by $10 \%$ MLE $+2 \% \mathrm{~B}+3 \% \mathrm{Ca}$ EDTA in the second season. However, the least values of antioxidant activity (50.87 and 57.91) were found with control treatment in the two seasons, respectively.

\section{Discussion}

Firmness, color, soluble solid content, and titratable acidity are the main important quality attributes in plums, although large variations in these parameters can be found depending on the cultivar, production area, climatic conditions, and harvest season (Crisosto et al. 2007; Díaz-Mula et al. 2008). However, plums are

Table 9 Effect of preharvest spraying with moringa leaf extract, boric acid, and chelated calcium on antioxidant activity of Hollywood plum fruits stored at $0 \pm 1{ }^{\circ} \mathrm{C}$ and $\mathrm{RH} 85-90 \%$ during 2018 and 2019 seasons

\begin{tabular}{|c|c|c|c|c|c|c|}
\hline \multirow[t]{2}{*}{ Treatments } & \multicolumn{6}{|c|}{ Storage period per weeks } \\
\hline & 0 & 2 & 4 & 6 & 8 & Mean \\
\hline & \multicolumn{6}{|c|}{ First season; 2018} \\
\hline $\mathrm{T} 1$ & $69.00 d$ & $68.26 \mathrm{e}$ & $57.11 \mathrm{~s}$ & $55.39 t$ & $55.03 \mathrm{u}$ & $60.95 \mathrm{C}$ \\
\hline T2 & $65.09 \mathrm{~g}$ & 62.441 & 60.110 & $58.02 r$ & $55.37 t$ & $60.21 \mathrm{D}$ \\
\hline T3 & $71.93 a$ & $70.62 b$ & $69.55 c$ & $65.23 f$ & $62.14 \mathrm{~m}$ & $67.89 \mathrm{~A}$ \\
\hline T4 & $64.85 i$ & $63.18 j$ & $62.64 k$ & $60.85 n$ & $59.17 p$ & $62.14 \mathrm{~B}$ \\
\hline Control & $64.93 \mathrm{~h}$ & $62.11 \mathrm{~m}$ & 60.050 & $58.21 q$ & $50.87 v$ & 59.07E \\
\hline \multirow[t]{2}{*}{ Mean } & $67.16 \mathrm{~A}$ & $65.32 \mathrm{~B}$ & $61.89 \mathrm{C}$ & 59.54D & $56.52 \mathrm{E}$ & \\
\hline & \multicolumn{6}{|c|}{ Second season; 2019} \\
\hline $\mathrm{T} 1$ & $67.40 \mathrm{e}$ & $67.00 \mathrm{~g}$ & $65.94 k$ & $63.14 p$ & $60.86 t$ & $64.87 C$ \\
\hline $\mathrm{T} 2$ & $68.46 c$ & $66.89 h$ & $65.77 \mid$ & $62.23 r$ & $60.54 u$ & 64.78D \\
\hline T3 & $69.88 a$ & $68.35 d$ & $66.00 j$ & $65.79 \mid$ & $60.00 \mathrm{v}$ & $66.00 \mathrm{~A}$ \\
\hline T4 & $68.84 b$ & $67.34 f$ & $65.27 \mathrm{~m}$ & $65.01 n$ & $63.00 q$ & $65.89 \mathrm{~B}$ \\
\hline Control & $66.60 \mathrm{i}$ & $66.00 \mathrm{j}$ & 63.440 & $61.25 \mathrm{~s}$ & $57.91 \mathrm{w}$ & $63.04 \mathrm{E}$ \\
\hline Mean & $68.24 \mathrm{~A}$ & $67.12 B$ & $65.28 \mathrm{C}$ & 63.48D & $60.46 \mathrm{E}$ & \\
\hline
\end{tabular}

Means in each column with similar letters are not significantly different 
categorized as climacteric fruit with a limited postharvest storage life due to evolution of the ripening process leading to pigment changes, softening, increase in SSC, and reduction in TA even if they are stored at cold temperature (Valero and Serrano 2010). In this study, Hollywood plums were sprayed preharvest with moringa leaf extract, boric acid, and chelated calcium to investigate its effects on fruit quality assessments and antioxidant during cold storage periods.

The results indicated that there was an increase in weight loss with a storage period in all treatments as well as control fruit (Table 1). Weight loss is a consequence of fruit dehydration due to changes in surface transfer resistance to water vapor, in respiration rate, and the occurrence of small fissures connecting the internal and external atmospheres (Woods 1990). Preharvest treatment with moringa leaf extract, boric acid, and chelated calcium recorded the lowest values of weight loss especially $5 \%$ MLE $+1 \%$ B $+2 \%$ Ca EDTA. These results agreed with (Tsomu and Patel 2014; Raja et al. 2015, and Kaur et al. 2019) the report that weight loss in calcium and boric acid treated fruit was lower than untreated during storage. It may be due to the role of calcium and boron applications that have shown to be effective in terms of membrane functionality and integrity maintenance (Pilbeam and Kirkby 1983), with lower losses of phospholipids and proteins and reduced ion leakage (Lester and Grusak 1999), which could be responsible for the lower weight loss.

Fruit firmness is the most important indicator for shelf life, preservation potential, consumer satisfaction, and market value of the fruits. The results indicated that there was a reduction in fruit firmness with prolonging storage period in all treatments as well as control fruit (Table 2), but the highest firmness value was obtained in treatment $10 \%$ MLE $+1 \% \mathrm{~B}+2 \%$ Ca EDTA in the two seasons. This increase in fruit firmness might be due to the high calcium content in moringa leaf extract (Mishra et al. 2013), which goes in parallel with those previously mentioned by Thanaa et al. (2017) who reported that foliar application of moringa leaf extract increased firmness of Hollywood plum, beside treatment with chelated calcium led to an increase of the concentration of calcium in treated fruit through active absorption and deposition of calcium in epicarp and mesocarp of fruits (Raja et al. 2015). In this respect, Crisosto and Michailides (1991) and Plich and Wojcik (2002) found that foliar preharvest calcium sprays effective in held on retain fruit firmness at harvest and consequently a slower softening during long-term storage at low temperature.

The effect of calcium on fruit firmness could be attributed to its role in stabilization of cell membrane and decrease fruit sorting, thus contributing to the firmness of fruit tissue that prevents physiological disorders, reduces rate of respiration and slow down ripening process, and prolonging shelf life of fruits (Picchioni et al. 1995).

However, the ripening of fruit during cold storage is accompanied by fruit softening and an increase in total sugar content that improves sensory quality. The improvement in sensory quality mainly coupled with a change in fruit color, raise in SSC, and decline in firmness and acidity (Kaur et al. 2019). Moringa leaf extract, boric acid, and chelated calcium treatments affected retention on higher sensory quality of Hollywood fruits at the end of storage.

These results are in agreement with those reported by Thanaa et al. (2017) who mentioned that foliar application of moringa leaf extract enhances plum fruit color, SSC, TA, and SSC:TA ratio. Moreover, Plich and Wojcik (2002) who reported that calcium treatments were more beneficial for plum fruit soluble solids than control.

Decreases in Hue color index show an intensification of purple color of plum skin, which usually occurs during ripening, either on tree or during storage (MartínezEsplá et al. 2017).

The higher sensory quality of fruits at the end of storage might be due to the high sugar, starch, and cytokinin content of Moringa oleifera leaves which promote carbohydrate metabolism and create new source-sink relationships leading to increase fruit soluble solid content (Dyer et al. 1990).

Besides, the role of calcium in retardation of ripening and fruit softening processes led to the development of better juiciness, texture, flavor, and sweetness (Shiri et al. 2014). Boric acid treatment retarded the rate of degradation of SSC and retained higher TA compared to untreated fruit, thus led to increase SSC: TA associated generally with ripening in climacteric fruit (Huan et al. 2016).

During storage fruits under cold conditions, it was observed that different patterns in the total phenolic content, anthocyanins, flavonoids, and antioxidant activity. Rapisarda et al. (2008) observed an increase in anthocyanins, flavanones, and antioxidant capacity during cold storage. Piljac-Žegarac and Šamec (2011) reported that small fruits like strawberries, raspberries, cherries, and sour cherries stored at $4{ }^{\circ} \mathrm{C}$ exhibited slightly higher antioxidant activity values. Moreover, correlations between antioxidant activity and phenolic components in different fruits were established (Grace et al. 2014; Galani et al. 2017a). It is interesting to note that preharvest treatments by moringa leaf extract, boric acid, and chelated calcium led to increased levels of total anthocyanin content, total flavonoid content, and total phenolic content in Hollywood plum fruits compared with control (Tables 6, 7, and 8).

Our findings on total anthocyanin content of fruits coincide with the results reported by (Piljac-Žegarac and 
Šamec 2011 and Leong and Oey 2011). They demonstrated that there was an increase of TAC during storage of fruits in cold conditions. They suggested that the release of membrane bound anthocyanins due to their degradation in plant tissues by enzyme systems such as glycosidases (anthocyanases), polyphenoloxidases, and peroxidases enhanced by cold condition can justify the higher TAC obtained after cold storage (Shi et al. 1992). Foliar application of moringa leaf extract increased anthocyanin content may be due to that the extract is rich in minerals which enhanced the activity of enzymes hence appearance of colored pigments.

The results of TFC agree with the findings of (DuPont et al. 2000), who found that total flavonoid content was decreased during storage.

Several other findings support our total phenolic content results (Galani et al. 2017b; Piljac-Žegarac and Šamec 2011, and Kevers et al. 2007). They illustrated that TPC increases during low-temperature storage. The increased synthesis of phenolic compounds under lowtemperature storage is a response of the plants against adverse climate conditions including chilling injury by synthesizing polyphenolic phytoalexins, through an increase of phenylalanine ammonialyase activity, coupled with low level of polyphenoloxidase activity that may reduce the oxidation of phenolic substrates to quinones (Leja et al. 2003; Lattanzio et al. 2009). These results go in parallel with those mentioned by Sarrwy et al. (2012) and Kamal et al. (2014). They demonstrated that preand postharvest treatments with calcium gave significantly higher total phenols than control during storage. The possible reason for higher total phenols with calcium treatments may be that calcium does not allow the mixing of polyphenol oxidase and oxidizable polyphenols by maintaining the membrane stability (Akhtar et al. 2010) which may also reduce the spoilage percentage in fruits.

The results of antioxidant activity agree with the findings of (Galani et al. 2017a) who mentioned that decrease of AA during storage of fruits. Decrease of AA during storage can be attributed to a decreased level of total phenolics, phenolic acids, vitamin $\mathrm{C}$, and other compounds like anthocyanins, carotenoids, and flavonoids when the fruits are stored (Galani et al. 2017b). Enhancement of antioxidant activity in Hollywood plum treated with moringa leaf extract, boric acid, and chelated calcium might be due to the high antioxidant content in extract of moringa leaf such as tocopherols, carotenoids, ascorbic acid, flavonoids, and different other phenolic compounds (Jacob and Shenbagaraman 2011); when applied to the trees, it affects on the metabolic process and subsequently increased the endogenous level of antioxidants. Additionally, preharvest treatment with moringa leaf extract, boric acid, and chelated calcium increased total anthocyanin content (Table 6) which considered natural antioxidants (SatueGracia et al. 1997) and increased the total phenolic content (Table 8) which closely correlated with antioxidant activity.

\section{Conclusions}

From the last illustrated results, we can conclude that all fruits preharvest treated by moringa leaf extract, boric acid, and chelated calcium showed the lowest significant differences in weight loss, hue angle, and the highest significant differences in firmness, lightness, soluble solids content:titratable acidity ratio, total anthocyanin content, total flavonoid content, total phenolic content, and antioxidant activity of Hollywood plum during cold storage compared with control especially $10 \%$ MLE $+1 \%$ B $+2 \%$ Ca EDTA, so this treatment can be used to maintain plum quality attributes and antioxidant compounds of plum fruits under cold storage conditions.

\section{Abbreviations}

MLE: Moringa leaf extract; B: Boric acid; Ca EDTA: Chelated calcium; TAC: Total anthocyanin content; TFC: Total flavonoid content; TPC: Total phenolic content; AA: Antioxidant activity

\section{Acknowledgements \\ The authors thank Prof. Dr. Abdalla AM at Department of Horticultural Crops Technology, Agricultural and Biological Division, National Research Center, Dokki, Giza, Egypt, for providing moringa leaves to conduct the experiment. \\ Authors' contributions \\ TSMM, FKMS, and GAME designed and conducted the field experiment treatments, following up plum fruits during storage periods, measured its physical properties, and performed the chemical analysis; TSMM and FKMS analyzed data and wrote the paper; all authors read, reviewed the manuscript, and approved the final version.}

\section{Authors' information}

Dr. Thanaa Shaban Mohamed Mahmoud 1 is an associate professor at Department of Horticultural Crops Technology, Agricultural and Biological Division, National Research Centre, Dokki, Giza, Egypt.

Dr. Fatma Korany Mohamed Shaaban is an associate professor at

Department of Fruit Handling Research, Horticultural Research Institute, Agricultural Research Centre, Giza, Egypt.

Dr. Gehan Abd El-Malek El-Hadidy is an associate professor at Department of Fruit Handling Research, Horticultural Research Institute, Agricultural Research Centre, Giza, Egypt.

\section{Funding}

No fund available.

\section{Availability of data and materials}

The datasets generated and/or analyzed during the current study are included in this published.

Ethics approval and consent to participate Not applicable

Consent for publication

Not applicable

Competing interests

The authors declare that they have no competing interests. 


\section{Author details}

'Department of Horticultural Crops Technology, National Research Centre, Dokki, Giza, Egypt. ${ }^{2}$ Fruit Handling Res. Dept., Hort. Res. Inst. Agric. Res. Cen., Giza, Egypt.

\section{Received: 19 November 2019 Accepted: 16 July 2020}

Published online: 22 September 2020

\section{References}

Akhtar A, Abbasi NA, Hussain A (2010) Effect of calcium chloride treatments on quality characteristics of loquat fruit during storage. Pak J Bot 42:181-188

Alandes L, Perez-Monuera I, Llarca E, Quiles A, Hernondo I (2009) Use of calcium lactate to improve structure of "Flor de Invierno" fresh cut pears. Postharvest Biol Technol 53:145-151

AOAC (2000) Official methods of analysis of the association of the analytical chemists, 17th edn. AOAC International, Washington DC

Chapin RE, Ku WW, Kenney MA, McCoy H (1998) The effects of dietary boric acid on bone strength in rats. Biol Trace Elem Res 66:395-399

Crisosto $\mathrm{CH}$, Michailides T (1991) A possible new role of calcium in postharvest technology. Perishables. Handling. Issue, 72: 10.

Crisosto GM, Crisosto CH, Echeverría G, Puy J (2007) Segregation of plum and pluot cultivars according to their organoleptic characteristics. Postharvest Biol Technol 44:271-276

Degraeve P, Saurel R, Coutel Y (2003) Vacuum impregnation pretreatment with pectin methyl esterase to improve firmness of pasteurized fruits. J Food Sci 68:716-721

Díaz-Mula HM, Zapata PJ, Guillén F, Castillo S, Martínez RD, Valero D, Serrano M (2008) Changes in physicochemical and nutritive parameters and bioactive compounds during development and on-tree ripening of eight plum cultivars: a comparative study. J Sci Food Agric 88:2499-2507

Donald DH, Gwathmey CO, Sams CE (1998) Foliar feeding on cotton: evaluation potassium sources, potassium solution buffering and boron. Agron J 90:740-746

Dong X, Wrolstad RE, Sugar D (2000) Extending shelf life of fresh-cut pears. J Food Sci 65:181-186

DuPont MS, Mondin Z, Williamson G, Price KR (2000) Effect antioxidants on human low-density lipoprotein and lecithin liposome content and composition of lettuce and endive. J Agric Food Chem 48:3957-3964

Dyer D, Cotterman D, Kerr PS, Carlson DR (1990) Cytokinins as metabolic stimulants which induce pod set. Plant Growth Substances Springer-Verlag: $67-70$

Galani YJH, Mankad MP, Shah AK, Patel NJ, Acharya RR, Talati JG (2017b) Effect of storage temperature on vitamin C, total phenolics, UPLC phenolic acids profile and antioxidant capacity of eleven Potato (Solanum tuberosum L.) Varieties. Hortic Plant J 3:73-89

Galani YJH, Patel JS, Patel NJ, Talati JG (2017a) Storage of fruits and vegetables in refrigerator increases their phenolic acids but decreases the total phenolics, anthocyanins and vitamin C with subsequent loss of their antioxidant capacity. Antioxidants 6(59):1-19

Giusti MM, Wrolstad RE (2001) Characterization and measurement of anthocyanins by UV-visible spectroscopy. In: Wrolstad RE, Schwartz SJ (eds) Current Protocols in Food Analytical Chemistry. Wiley, New York, pp 1-13

Grace MH, Yousef GG, Gustafson SJ, Truong VD, Yencho GC, Lila MA (2014) Phytochemical changes in phenolics, anthocyanins, ascorbic acid, and carotenoids associated with sweet potato storage and impacts on bioactive properties. Food Chem 145:717-724

Hemat MK, Eissa MA, Albayaty AA (2014) Effect of calcium and boron foliar application on postharvest quality of Florida Prince peach fruit. J Horticult Sci Ornamental Plants 6(1):34-40

Huan C, Jiang L, Xivjuan A, Kang R, Mingling Y, Ruijuan M, Zhifang Y (2016) Potential role of glutathione peroxidase gene family in peach fruits ripening under combined postharvest treatment with heat and 1-MCP. Postharvest Biol Technol 111:175-184

Ismail HK, Mehmet A, Hacer C (2009) Antioxidant capacity, total phenolics and some chemical properties of semi-matured apricot cultivars grown in Malatya, Turkey. World Appl Sci J 6(4):519-523

Jacob SJP, Shenbagaraman S (2011) Evaluation of antioxidant and antimicrobial activities of the selected green leafy vegetables. Int J Pharm Tech Res 3:148-152

Kamal HM, Eissa MA, Albayaty AA (2014) Effect of calcium and boron foliar application on postharvest quality of Florida Prince peach fruit. J Hort Sci Ornamental Plants 6:34-40
Kaur A, Gill PPS, Jawandha SK, Singh M (2019) Pre-storage exogenous application of boric acid extends storability and maintains quality of pear fruits. Sci Hortic 256:1-9

Kevers C, Falkowski M, Tabart J, Defraigne JO, Dommes J, Pincemail J (2007) Evolution of antioxidant capacity during storage of selected fruits and vegetables. J Agric Food Chem 55:8596-8603

Khalifa RKM, Omaima MH, Abd-El-Khair H (2009) Influence of foliar spraying with boron and calcium on productivity, fruit quality, nutritional status and controlling of blossom end rot disease of Anna apple trees. World J Agric Sci 5:237-249

Lattanzio V, Kroon PA, Quideau S, Treutter D (2009) Plant phenolics—secondary metabolites with diverse functions. In: Recent Advances in Polyphenol Research, vol 1. Wiley, Hoboken, pp 1-35

Leja M, Mareczek A, Ben J (2003) Antioxidant properties of two apple cultivars during long-term storage. Food Chem 80:303-307

Lelièvre JM, Tichit L, Dao P, Fillion L, Nam YW, Pech JC, Latché A (1997) Effect of chilling on the expression of ethylene biosynthetic genes in Passe-Crassane pear (Pyrus communis L.) fruits. Plant Mol Biol 33:847-855

Leong SY, Oey I (2011) Effects of processing on anthocyanins, carotenoids and vitamin C in summer fruits and vegetables. Food Chem 133:1577-1587

Lester GE, Grusak MA (1999) Postharvest application of calcium and magnesium to honeydew and netted muskmelon: effects on tissue ion concentrations, quality and senescence. Am Soc Hort Sci 124:545-552

Martínez-Esplá A, Serrano M, Valero D, Martínez-Romero D, Castillo S, and Zapata PJ (2017) Enhancement of antioxidant systems and storability of two plum cultivars by preharvest treatments with salicylates. Int J Mol Sci 18, 1911:1-14

Mc Gire RG (1992) Reporting of objective color measurements. Hort Sci 27(12):Dec

Meighani H, Ghasemnezhad M, Bakhshi D (2014) Evaluation of biochemical composition and enzyme activities in browned arils of pomegranate fruits. Int J Horticult Sci Technol 1(1):53-65

Nasira M, Khan AS, Basra SMA, Malik AU (2016) Foliar application of moringa leaf extract, potassium and zinc influence yield and fruit quality of 'Kinnow' mandarin. Sci Hortic 210:227-235

Omaima MH, Maksoud MA, Nagwa SZ, Malaka AS (2011) Use pre-harvest treatments to keeping quality and long shelf life of some date palm cultivars. ve ark. / Selçuk Tarım ve Gıda Bilimleri Dergisi 25, 1: 65-74

Mishra SP, Singh P, Singh S, Das R, Prasad RS (2013) Moringa oleifera leaf extract as biostimulant for increasing pea yield. Indian Forester 139(6)562-563.

Phiri C, Mbewe DN (2010) Influence of Moringa oleifera leaf extracts on germination and seedling survival of three common legumes. Int J Agric Biol 12:315-317

Picchioni GA, Watada AE, Conway WS, Whitaker BD, Sams CE (1995) Phospholipid, galactolipid and steryl lipid composition of apple fruit cortical tissue following postharvest $\mathrm{CaCl}_{2}$ nitration. Phytochemistry 39(4):763-769

Pilbeam DJ, Kirkby EA (1983) The physiological role of boron in plants. J Plant Nutr 6:563-582

Piljac-Žegarac J, Šamec D (2011) Antioxidant stability of small fruits in postharvest storage at room and refrigerator temperatures. Food Res Int 44:345-350

Plich H, Wojcik P (2002) The effect of calcium and boron foliar application on postharvest plum fruit quality. Acta Hortic 594:445-451

Raja RHS, Bhat ZA, Malik AR, Shafi RH (2015) Interrelationship between fruit quality and pre-harvest calcium chloride treatment on peach Cv.'Shan-IPunjab'. International Journal of Agriculture. Environ Biotechnol 8(1):103-109

Rapisarda P, Lo Bianco M, Pannuzzo P, Timpanaro N (2008) Effect of cold storage on vitamin C, phenolics and antioxidant activity. Postharvest Biol Technol 49: 348-354

Sarrwy SMA, Gadalla EG, Mostafa EAM (2012) Effect if calcium nitrate and boric acid sprays on fruit set, yield and fruit quality of cv. Amhat date palm. World J Agric Sci 8:506-515

SatueGracia MT, Heinonen M, Frankel E (1997) Anthocyanins as antioxidants on human low-density lipoprotein and lecithin-liposome systems. J Agric Food Chem 45(9):3362-3367

Shear CB (1975) Calcium related disorders of fruit and vegetables. HortSci 10: 361-365

Sheren AA, El-Amary El (2015) Improving growth and productivity of "Pear" trees using some natural plants extracts under north Sinai conditions. J Agric Veter Sci 8:1-9

Shi X, Li B, Qin G, Tian S (2012) Mechanism of antifungal action of borate against Colletotrichum gloeosporioides related to mitochondrial degradation in spores. Postharvest Biol Technol 67:138-143 
Shi ZU, Bassa IA, Gabriel SL, Francis FJ (1992) Anthocyanin pigments of sweet potatoes - pomoea batatas. J Food Sci 55:755-757

Shiri MA, Moghaddam GM, Ebrahimi R (2014) Fruit growth and sensory evaluation of 'Hayward' kiwifruit in response to preharvest calcium chloride application and orchard location. Agric Conspec Sci 79:183-189

Shirzadeh E, Kazemi M (2011) Effect of malic and calcium treatments on quality characteristics of apple fruits during storage. Amer j plant Phy 6:176-182

Siddhuraju P, Becker K (2003) Antioxidant properties of various solvent extracts of total phenolic constituents from three different agroclimatic origins of drumstick tree (Moringa oleifera Lam.) leaves. J Agric Food Chem 51:2144-2155

Snedecor GW, Cochran WG (1990) Statistical methods ( $7^{\text {th }}$ Ed) lowa State Univ USA, pp 593

Thanaa SM, Kassim NE, AbouRayya MS, Abdalla AM (2017) Influence of foliar application with moringa (Moringa oleifera L.) leaf extract on yield and fruit quality of Hollywood plum cultivar. J Hortic 193:1-7

Tsomu T, Patel HC (2014) Effect of post-harvest treatments of chemical and plant growth regulators on physical parameters of sapota fruit cv. Kalipatti. J Food Process Technol 5:347-349

Valero D, Serrano M (2010) Postharvest biology and technology for preserving fruit quality. CRC Press, Boca Raton, pp 7-68

Woods JL (1990) Moisture loss from fruits and vegetables. Postharvest News Info 1:195-199

Xuan H, Streif J, Romheld V, Bangerth F (2005) Application of boron with calcium affects respiration and ATP/ADP ratio in "Conference" pears during controlled atmosphere storage. J Hortic Sci Biotechnol 80:633-637

Zhishen J, Mengcheng T, Jianming W (1999) The determination of flavonoid contents in mulberry and their scavenging effects on superoxide radicals. Food Chem 64:555-559

\section{Publisher's Note}

Springer Nature remains neutral with regard to jurisdictional claims in published maps and institutional affiliations.

\section{Submit your manuscript to a SpringerOpen ${ }^{\circ}$ journal and benefit from:}

- Convenient online submission

- Rigorous peer review

- Open access: articles freely available online

High visibility within the field

- Retaining the copyright to your article

Submit your next manuscript at $\boldsymbol{\nabla}$ springeropen.com 